\title{
Elevated Troponin after Stroke: A Systematic Review
}

\author{
Gillian Kerr ${ }^{\mathrm{a}}$ Gautamananda Ray $^{\mathrm{a}}$ Olivia Wu $^{\mathrm{b}}$ David J. Stott ${ }^{\mathrm{a}}$ \\ Peter Langhorne ${ }^{a}$ \\ ${ }^{a}$ Academic Section of Geriatric Medicine, Faculty of Medicine, University of Glasgow, Glasgow Royal Infirmary,

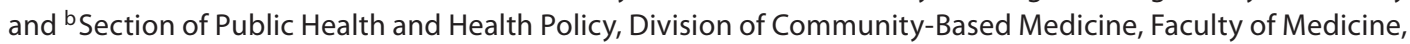 \\ University of Glasgow, Glasgow, UK
}

\section{Key Words}

Troponin · Electrocardiogram changes $\cdot$ Myocardial ischemia $\cdot$ Stroke

\begin{abstract}
Background: Troponin levels are elevated in some acute stroke patients, but the clinical significance of this is unclear. Methods: We conducted a systematic review of studies measuring troponin within 7 days of symptom onset in acute stroke patients. Results: We identified 15 studies (2,901 patients). Overall $18.1 \%(95 \% \mathrm{Cl} 13.6-22.6)$ had a positive troponin level. These patients were more likely to have electrocardiogram (ECG) changes suggestive of myocardial ischemia (OR 3.0; 95\% Cl 1.5-6.2), and there was an independent association with death (OR 2.9; 95\% Cl 1.7-4.8). Conclusion: Elevated troponin level after acute stroke is common and is associated with ECG changes suggestive of myocardial ischemia and increased risk of death.
\end{abstract}

Copyright $\odot 2009$ S. Karger AG, Basel

\section{Introduction}

Troponin is a highly sensitive and specific marker of myocardial necrosis that is used in the diagnosis of acute myocardial infarction and for risk stratification of patients with acute coronary symptoms. It is also elevated in some acute stroke patients [1-3]. The quoted prevalence of a positive troponin level in acute stroke varies but has been reported to be as high as 34\% [4]. There is a complex overlap between cardiovascular and cerebrovascular disease and the cause of troponin rise in acute stroke is not clear. In some patients, raised troponin could reflect an association of coronary artery disease and acute stroke. However, it has also been suggested that some of the myocardial damage observed in acute stroke is due to patchy myocyte damage (myocytolysis) due to activation of the sympathoadrenal system that may be linked to insular damage $[1,5]$.

Not only is the cause of an elevated troponin level unclear, but also its clinical significance. Some studies have reported an independent association with both case fatality $[2,6,7]$ and the combined poor outcome of mortality or disability $[4,8]$. However, other investigators have found no independent association [1].

Prof. Peter Langhorne

Academic Section of Geriatric Medicine, Room disc 35, 3rd Floor, University Block Glasgow Royal Infirmary

Glasgow G31 2ER (UK)

Tel. +44 141211 4976, Fax +44 141211 4033, E-Mail p.langhorne@clinmed.gla.ac.uk 
Two previous narrative reviews $[9,10]$ have commented on the relationship between troponin and stroke. However, neither has included all available studies nor have they used a systematic review approach with metaanalysis, summary statistics and clear end points [11]. We therefore did a rigorous systematic review of studies of troponin measurement in acute stroke to estimate the overall prevalence of elevated troponin as well as the potential association between elevated troponin and electrocardiogram (ECG) changes, death and functional outcome.

\section{Methods}

\section{Review Questions}

Our review objectives were to establish, in patients with acute stroke, (1) the prevalence of elevated troponin, (2) the association of elevated troponin with ECG changes suggestive of myocardial ischemia, and (3) the association of elevated troponin with clinical outcomes (death and death or disability).

\section{Search Strategy and Selection Criteria}

We identified articles (from inception to September 2007) through searches of Embase, Medline and the Cochrane Library (Issue 3, 2007). A librarian devised the search strategy using the key terms 'troponin', 'stroke' and 'cerebrovascular accident'. We limited searches to adult populations. We also searched the references of relevant publications. There were no language restrictions.

Eligible studies had to have recruited acute stroke patients within 1 week of onset. We included both ischemic and hemorrhagic stroke. Recruitment had to include consecutive admissions with routine measurement of troponin T or troponin I. Comparisons were made between those with or without elevated troponin levels according to the author's definition.

\section{Data Extraction}

Two independent reviewers screened all titles and abstracts. Abstracts were excluded if both reviewers agreed on exclusion. Disagreements were resolved by discussion. Relevant abstracts were then reviewed as full papers for inclusion and data extraction. We collected patient details including age, stroke type and ECG findings plus the clinical outcomes of death and dependency. The type of troponin assay used and the cutoff threshold for an elevated level were also recorded.

\section{Data Analysis and Statistics}

We calculated the proportion of patients who were troponin positive for each study, together with the standard error of that proportion. The results of individual studies were then combined using a generic inverse variance approach [12], by calculating the log of the prevalence, together with the log of the standard error. This provided a summary result [with a $95 \%$ confidence interval (CI)] for all available studies that was weighted by the reciprocal of the variance.

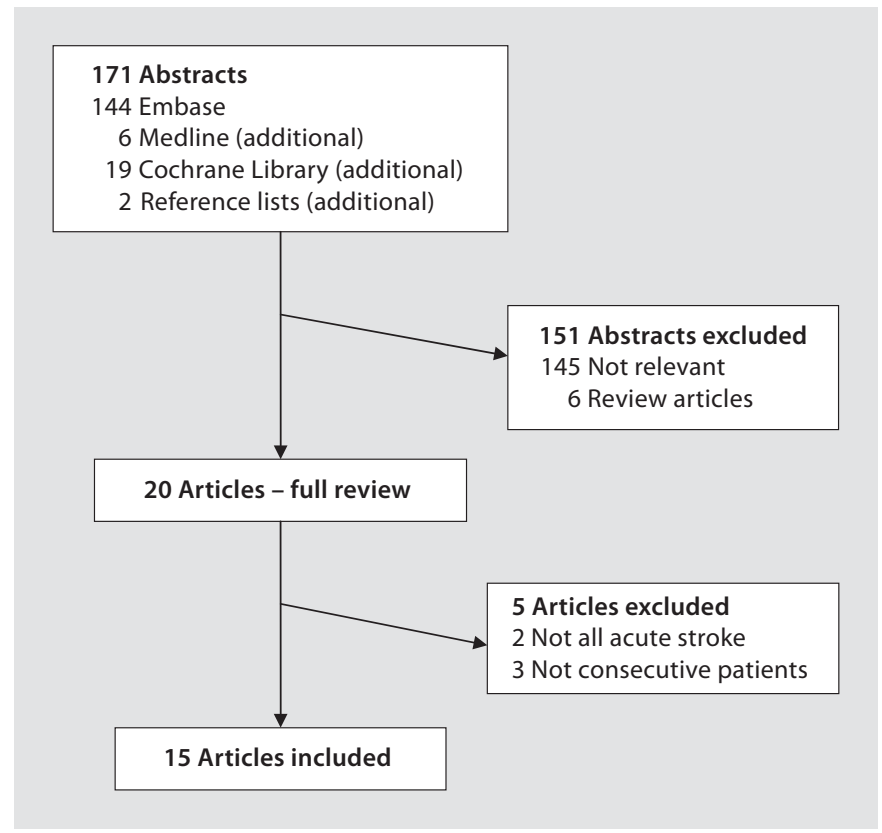

Fig. 1. Search flow and manuscript selection; articles on troponin and acute stroke.

We calculated univariate associations of troponin positivity with dichotomous outcomes (such as death, disability or ECG abnormalities) as the odds ratio (OR) and 95\% CIs. These data were calculated for individual studies and pooled using a random effects model. The DerSimonian and Laird random effects model was used for generic inverse variance analyses and the MantelHaenszel model for analyses of dichotomous data [12].

We also explored the relationship between troponin positivity with death and poor outcome (death or disability) within data which had undergone multivariate adjustment. These analyses used a generic inverse variance approach to calculate the log-adjusted OR and 95\% CI and a pooled OR with 95\% CIs for a group of studies. In each analysis, we calculated the degree of heterogeneity and efforts were made to explain sources of heterogeneity. All analyses used Revman 5.0 software [12].

\section{Results}

Figure 1 describes the literature search which identified 171 titles, all of which were scrutinized by two independent reviewers. We excluded 145 abstracts that were not relevant and 6 from review articles. A further review of full papers was done on the remaining 20 full articles. Three articles did not recruit consecutive referrals of acute stroke patients and 2 articles contained patients with other neurological conditions as well as acute stroke. This left 15 studies that were included in the review.

Cerebrovasc Dis 2009;28:220-226 
Table 1. Studies evaluating troponins in patients with acute stroke

\begin{tabular}{|c|c|c|c|c|c|c|}
\hline $\begin{array}{l}\text { Source and } \\
\text { country }\end{array}$ & Study population & $\begin{array}{l}\text { Patients } \\
\text { with previous } \\
\text { cardiac disease } \\
\text { excluded }\end{array}$ & $\begin{array}{l}\text { Patients with } \\
\text { previous renal } \\
\text { impairment } \\
\text { excluded }\end{array}$ & $\begin{array}{l}\text { Sampling } \\
\text { time }\end{array}$ & $\begin{array}{l}\text { Troponin } \\
\text { assay type/ } \\
\text { cutoff }^{1}\end{array}$ & Study end point \\
\hline $\begin{array}{l}\text { Barber et al. [1] } \\
\text { UK }\end{array}$ & $\begin{array}{l}\text { ischemic stroke patients in a stroke unit, } \\
\text { followed up for } 30 \text { days }(n=222)\end{array}$ & no & no & $\begin{array}{l}\text { within } 24 \mathrm{~h} \\
\text { of stroke }\end{array}$ & $\mathrm{I}>0.2$ & $\begin{array}{l}\text { death or } \\
\text { dependence }\end{array}$ \\
\hline $\begin{array}{l}\text { Jensen et al. [2] } \\
\text { Denmark }\end{array}$ & $\begin{array}{l}\text { ischemic stroke patients, followed up for an } \\
\text { average of } 19 \text { months }(n=244)\end{array}$ & yes & no & $\begin{array}{l}\text { within } 7 \text { days } \\
\text { of stroke }\end{array}$ & $\mathrm{T}>0.03$ & death \\
\hline $\begin{array}{l}\text { Ay et al. [3] } \\
\text { USA }\end{array}$ & $\begin{array}{l}\text { ischemic stroke patients in an academic center } \\
(\mathrm{n}=738)\end{array}$ & yes & yes & $\begin{array}{l}\text { within } 72 \mathrm{~h} \\
\text { of stroke }\end{array}$ & $\mathrm{T} \geq 0.1$ & $\begin{array}{l}\text { infarctions in } \\
\text { specific brain } \\
\text { regions }\end{array}$ \\
\hline $\begin{array}{l}\text { Fure et al. }[8] \\
\text { Norway }\end{array}$ & $\begin{array}{l}\text { ischemic stroke patients in a stroke unit, } \\
\text { followed up to discharge (mean } 9.9 \pm 5.8 \text { days) } \\
(\mathrm{n}=279)\end{array}$ & yes & no & $\begin{array}{l}\text { 'as soon as } \\
\text { diagnosis } \\
\text { made' }\end{array}$ & $\mathrm{T}>0.04$ & $\begin{array}{l}\text { death or } \\
\text { dependence }\end{array}$ \\
\hline $\begin{array}{l}\text { Apak et al. [13] } \\
\text { Turkey }\end{array}$ & $\begin{array}{l}\text { stroke patients in a neurological intensive care } \\
\text { unit }(\mathrm{n}=62)\end{array}$ & yes & yes & $\begin{array}{l}\text { within } 24 \mathrm{~h} \\
\text { of stroke }\end{array}$ & $\mathrm{T}>0.1$ & $\begin{array}{l}\text { myocardial injury } \\
\text { after stroke }\end{array}$ \\
\hline $\begin{array}{l}\text { Atam et al. [6] } \\
\text { India }\end{array}$ & $\begin{array}{l}\text { young stroke patients ( }<45 \text { years) in medical or } \\
\text { neuromedical wards, followed up to discharge } \\
(\mathrm{n}=40)\end{array}$ & no & no & $\begin{array}{l}12-24 \mathrm{~h} \text { after } \\
\text { admission }\end{array}$ & $\mathrm{T}>0.1$ & death \\
\hline $\begin{array}{l}\text { Di Angelantonio } \\
\text { et al. [7] Italy }\end{array}$ & $\begin{array}{l}\text { ischemic stroke patients in a stroke unit, } \\
\text { scheduled follow-up } 6 \text { months minimum } \\
\text { (mean } 152 \text { days) }(\mathrm{n}=330)\end{array}$ & no & no & $\begin{array}{l}\text { on admission } \\
\text { to stoke unit }\end{array}$ & $\mathrm{I} \geq 0.1$ & death \\
\hline $\begin{array}{l}\text { Iltumur et al. } \\
\text { [14] Turkey }\end{array}$ & $\begin{array}{l}\text { first ischemic stroke in a neurological intensive } \\
\text { care unit }(\mathrm{n}=57)\end{array}$ & yes & yes & $\begin{array}{l}\text { within } 24 \mathrm{~h} \\
\text { of stroke }\end{array}$ & I $>1.0$ & NT-proBNP levels \\
\hline $\begin{array}{l}\text { Maliszewska et } \\
\text { al. [15] Poland }\end{array}$ & $\begin{array}{l}\text { ischemic stroke patients, followed up for } 6 \\
\text { months }(\mathrm{n}=196)\end{array}$ & yes & no & $\begin{array}{l}\text { within } 72 \mathrm{~h} \\
\text { of stroke }\end{array}$ & $\mathrm{I}>0.1$ & death \\
\hline $\begin{array}{l}\text { Christensen et } \\
\text { al. [4] Denmark }\end{array}$ & $\begin{array}{l}\text { patients with cerebral infarction on CT without } \\
\text { dementia or life-threatening illness in a stroke } \\
\text { unit, followed up for } 3 \text { months }(n=155)\end{array}$ & no & no & $\begin{array}{l}\text { within } 24 \mathrm{~h} \\
\text { of stroke }\end{array}$ & $\mathrm{I}>0.1$ & $\begin{array}{l}\text { death or } \\
\text { dependence }\end{array}$ \\
\hline $\begin{array}{l}\text { Etgen et al. [16] } \\
\text { Germany }\end{array}$ & $\begin{array}{l}\text { ischemic stroke patients, followed up for } 90 \\
\text { days }(n=174)\end{array}$ & yes & no & $\begin{array}{l}\text { within } 12 \mathrm{~h} \\
\text { of stroke }\end{array}$ & $\begin{array}{l}\text { T and } \mathrm{I}>0.03 \\
(103 \text { had } \\
\text { I measured })\end{array}$ & $\begin{array}{l}\text { death or } \\
\text { dependence }\end{array}$ \\
\hline $\begin{array}{l}\text { Guerrero-Peral } \\
\text { et al. [17] Spain }\end{array}$ & $\begin{array}{l}\text { acute cerebrovascular disease patients, followed } \\
\text { up to discharge }(n=42)\end{array}$ & no & no & $\begin{array}{l}\text { within } 96 \mathrm{~h} \\
\text { of stroke }\end{array}$ & $\mathrm{T}$ and $\mathrm{I}>0.1$ & death \\
\hline $\begin{array}{l}\text { Ay et al. [18] } \\
\text { Turkey }\end{array}$ & first ischemic stroke patient $(\mathrm{n}=32)$ & yes & no & $\begin{array}{l}\text { within } 24 \mathrm{~h} \\
\text { of stroke }\end{array}$ & $\mathrm{T}>0.1$ & $\begin{array}{l}\text { cardiac enzymes } \\
\text { after stroke }\end{array}$ \\
\hline $\begin{array}{l}\text { Trooyen et al. } \\
\text { [19] Norway }\end{array}$ & $\begin{array}{l}\text { acute stroke patients, followed up to discharge } \\
(\mathrm{n}=149)\end{array}$ & no & no & $\begin{array}{l}\text { within } 24 \mathrm{~h} \\
\text { of stroke }\end{array}$ & $\mathrm{I}>0.4$ & death \\
\hline $\begin{array}{l}\text { James et al. [20] } \\
\text { New Zealand }\end{array}$ & $\begin{array}{l}\text { ischemic stroke patients in general wards, } \\
\text { followed up for } 60 \text { days }(n=181)\end{array}$ & no & no & $\begin{array}{l}12-72 \mathrm{~h} \text { after } \\
\text { admission }\end{array}$ & $\mathrm{T}>0.1$ & death \\
\hline
\end{tabular}

${ }^{1}$ Units are either $\mathrm{ng} / \mathrm{ml}$ or $\mu \mathrm{g} / \mathrm{l}$, which are equivalent.

Details of the included studies are summarized in table 1. A variety of different troponin assays and cutoffs were used. In addition, some studies excluded patients with known cardiac disease or renal impairment while others did not. We used the investigators' definition of troponin positive. One study [17] measured both troponin $\mathrm{T}$ and $\mathrm{I}$ in all patients; we elected to use the troponin $\mathrm{T}$ data for analysis of this paper. Overall $18.1 \%$ (95\% CI 13.6-22.6) of acute stroke patients had a positive troponin level (fig. 2). In one study [18], no patients were found to have a positive troponin level. Results were consistent across the different troponin assay/cut- 


\begin{tabular}{|c|c|c|c|}
\hline $\begin{array}{l}\text { Study } \\
\text { or subgroup }\end{array}$ & $\begin{array}{l}\text { Percent } \\
\text { positive }\end{array}$ & SE & $\begin{array}{l}\text { Percent positive } \\
(95 \% \mathrm{Cl})\end{array}$ \\
\hline \multicolumn{4}{|l|}{ Troponin $T<0.1$} \\
\hline Etgen et al. [16] & 4.6 & 1.19 & $=$ \\
\hline Fure et al. [8] & 9.3 & 1.7 & - \\
\hline Jensen et al. [10] & 10.3 & 1.9 & $=$ \\
\hline Subtotal $(95 \% \mathrm{Cl})$ & & & 7.86 \\
\hline \multicolumn{4}{|l|}{ Troponin $T \geq 0.1$} \\
\hline Apak et al. [13] & 32.3 & 5.9 & $\rightarrow$ \\
\hline Atam et al. [6] & 35 & 7.5 & $\Longrightarrow$ \\
\hline Ay et al. [18] & 0 & - & 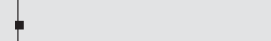 \\
\hline Ay et al. [3] & 6.7 & 0.9 &. \\
\hline Guerrero-Peral et al. [17] & 14.29 & 4.38 & $=$ \\
\hline James et al. [20] & 16.6 & 2.7 & $\rightarrow$ \\
\hline Subtotal $(95 \% \mathrm{Cl})$ & & & 19.34 \\
\hline \multicolumn{4}{|l|}{ Troponin $1<0.1$} \\
\hline Christensen et al. [4] & 33.6 & 3.8 & $\rightarrow$ \\
\hline Di Angelantonio et al. [7] & 10.6 & 1.7 & - \\
\hline Maliszewska et al. [15] & 34.2 & 3.4 & $\rightarrow$ \\
\hline Subtotal $(95 \% \mathrm{Cl})$ & & & 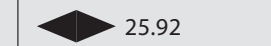 \\
\hline \multicolumn{4}{|l|}{ Troponin $1 \geq 0.1$} \\
\hline Barber et al. [1] & 20.3 & 2.7 & $=$ \\
\hline Iltumur et al. [14] & 15.8 & 4.8 & $\rightarrow$ \\
\hline Trooyen et al. [19] & 26.9 & 3.6 & - \\
\hline Subtotal $(95 \% \mathrm{Cl})$ & & & 21.43 \\
\hline \multirow{3}{*}{$\begin{array}{l}\text { Total }(95 \% \mathrm{Cl}) \\
\text { Heterogeneity: } \mathrm{I}^{2}=93 \%\end{array}$} & & & $18.11[13.59,22.63]$ \\
\hline & & & $\begin{array}{ll}1 \\
50 & 100\end{array}$ \\
\hline & & & Percent frequency \\
\hline
\end{tabular}

Fig. 2. Prevalence of positive troponin in acute stroke patients shown in troponin assay type/cutoff groups. off groups except for a subgroup of studies that used a low cutoff for troponin, where the overall prevalence was lower, but this may be explained by other confounding factors.

Baseline characteristics of the patients included in the studies are likely to have influenced the prevalence of elevated troponin and explain some of the heterogeneity in the results; they are shown in the first four columns of table 1. Studies that excluded patients with known cardiac disease had, as expected, a lower prevalence of positive troponin than those which had not excluded previous cardiac disease [10.2\% (95\% CI $6.0-14.5)$ vs. $21.7 \%$ (95\% CI 15.4-28.0)]. The definition of cardiac disease varied but included recent myocardial infarction and arrhythmia. However, there was no significant difference between studies which had or had not excluded patients with previous renal impairment. We also compared studies that took place in an intensive care setting against those which did not, and studies which used troponin $\mathrm{T}$ versus troponin I. Differing troponin assay (T or I) did not explain heterogeneity, but difference in study setting may partly explain heterogeneity.

Acute stroke patients with a positive troponin level (fig. 3) were more likely to have features suggestive of myocardial ischemia on the ECG (OR 3.03; 95\% CI 1.496.17). The definition of ECG changes suggestive of myocardial infarction was generally described as either being ST depression or elevation, but some studies did not fully describe their criteria and the author's definition was accepted. Forty-three percent of those with elevated troponin had ECG changes suggestive of myocardial ischemia compared to $23 \%$ of those who did not. However, this

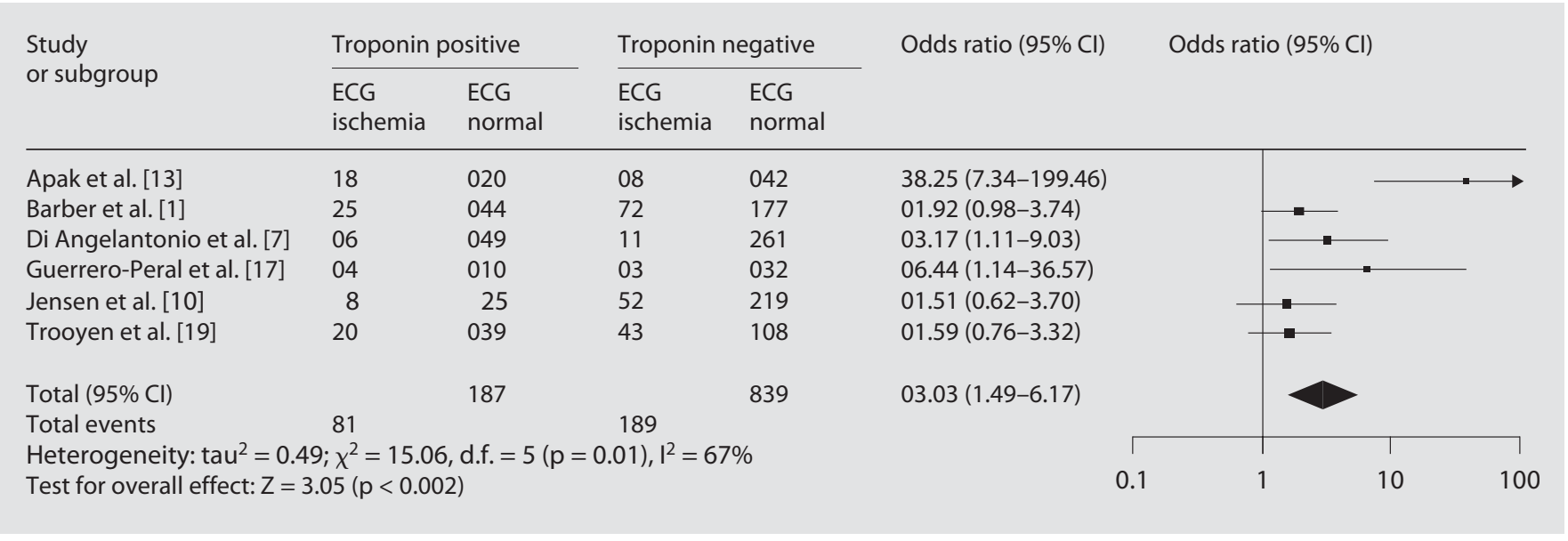

Fig. 3. The association between positive troponin and ECG changes suggestive of myocardial ischemia in patients with acute stroke. 
Table 2. Associations of positive troponin (I or T) with adverse outcome (death and death or dependence)

\begin{tabular}{|c|c|c|c|}
\hline & Unadjusted risk ratio & Adjusted risk ratio & Variables in final model \\
\hline \multicolumn{4}{|l|}{ Death } \\
\hline Atam et al. [6] & $28.11(5.14-154.22)$ & $12.35(1.61-94.95)$ & troponin $\mathrm{T}$, smoking, high blood pressure \\
\hline Barber et al. [1] & $6.31(2.73-14.59)$ & $3.36(1.22-9.26)$ & data not available \\
\hline Di Angelantonio et al. [7] & $8.43^{\mathrm{a}}(4.13-17.22)$ & $2.14^{\mathrm{a}}(1.13-4.05)$ & $\begin{array}{l}\text { positive troponin I, age, National Institutes of } \\
\text { Health Stroke Scale }\end{array}$ \\
\hline Guerrero-Peral et al. [17] & $6.43(0.9-46.06)$ & no multivariate analysis & no multivariate analysis \\
\hline James et al. [20] & $4.63(1.93-11.11)$ & not reported & $\begin{array}{l}\text { troponin } \mathrm{T} \text {, age, altered Glasgow Coma Scale at pre- } \\
\text { sentation }\end{array}$ \\
\hline Jensen et al. [2] & $11.40(4.61-28.15)$ & $3.39(1.34-8.6)$ & $\begin{array}{l}\text { positive troponin } \mathrm{T} \text {, age, Scandinavian Stroke Scale, } \\
\text { combined heart failure and renal failure }\end{array}$ \\
\hline Maliszewska et al. [15] & $1.87(0.85-4.10)$ & no multivariate analysis & no multivariate analysis \\
\hline Trooyen et al. [19] & $0.78(0.15-3.93)$ & no multivariate analysis & no multivariate analysis \\
\hline Pooled risk ratio & $5.34(2.85-10.02)$ & $2.87(1.72-4.78)$ & \\
\hline \multicolumn{4}{|l|}{ Death or dependence } \\
\hline Barber et al. [1] & $2.17(1.05-4.47)$ & $0.91(0.34-2.45)$ & $\begin{array}{l}\text { age, nat. } \log \text { C-reactive protein, Scandinavian Stroke } \\
\text { Scale }\end{array}$ \\
\hline Fure et al. [8] & $3.78(1.25-11.42)$ & $3.44(1.41-8.33)$ & $\begin{array}{l}\text { positive troponin } \mathrm{T}, \mathrm{Q} \text { wave, QT interval corrected } \\
\text { for rate }\end{array}$ \\
\hline Christensen et al. [4] & data not available & $4.10(1.3-14.5)$ & $\begin{array}{l}\text { positive troponin I, age, Scandinavian Stroke Scale } \\
\text { at admission, prestroke modified Rankin scale }\end{array}$ \\
\hline Pooled risk ratio & $2.45(1.31-4.57)$ & $2.31(0.91-5.86)$ & \\
\hline
\end{tabular}

analysis (fig. 3) is based on crude ORs and could not take into account potential confounding or effect-modifying factors.

Table 2 shows the association between a positive troponin level and the outcome of death at the end of scheduled follow-up. One study [16] could not be included as there were insufficient follow-up data. Acute stroke patients with a positive troponin level were at significantly greater risk of death than those without a troponin rise (OR 5.34; 95\% CI 2.85-10.02); however, this result showed significant heterogeneity $\left(\mathrm{I}^{2} 68 \%\right)$ and is based on data from univariate analyses, not adjusting for confounders.

Several studies used multivariate models to explore the relationship between troponin positivity and death (or the poor outcome of death or dependency) recorded at the end of scheduled follow-up (table 2). The variables included in models differed between studies, but generally included age and some measure of stroke severity. Even when adjusted for potential confounding, a positive troponin level was associated with an overall increased risk of both death and death or disability. The overall OR for death was 2.87 (95\% CI 1.72-4.78) and 2.31 (95\% CI 0.91-5.86) for death or disability.

\section{Discussion}

The results of our review indicate that elevated troponin in acute stroke is common, occurring in around 1 in 5 patients. We accepted the study investigators' definition of troponin positivity but acknowledge that the issue of different troponin types, assays and cutoffs is complex [21]. It is also beyond the scope of this systematic review to investigate the effect of different troponin types and cutoffs. The prevalence of elevated troponin was reasonably consistent across most of the different types of troponin assay and choice of threshold. However, there was residual heterogeneity between studies. In particular the three studies that used troponin $\mathrm{T}$ at a low cutoff of $<0.1$ $[2,8,16]$ had a lower prevalence of positivity compared to 
those studies with a higher cutoff. This counterintuitive observation may be due to the fact that these studies also excluded patients with preexisting cardiac disease.

Our second finding is that patients with elevated troponin were more likely to have ECG changes suggestive of myocardial ischemia, but this was not a universal finding in all studies. There are a number of possible causes of myocardial damage and raised troponin after stroke. Some patients may have had an acute coronary syndrome such as NSTEMI (non-ST elevation myocardial infarct). Others may have had myocytolysis with patchy myocyte damage associated with sympathoadrenal activation and a stress response after stroke. A few may have other causes of raised troponin such as pulmonary embolism or renal failure. However, we do not have evidence from the existing literature to establish the cause or causes of elevated troponin after acute stroke.

This review reinforces the view that elevated troponin is associated with poor outcomes but has not fully established if elevated troponin is an independent prognostic factor. It is possible that the positive troponin level is just a marker of stroke severity. However, 2 of the 4 studies that did a multivariate analysis $[2,7]$ and included a measure of stroke severity in that analysis found that troponin was an independent predictor of death.

The main strength of our review is that we have used a rigorous systematic review approach [11] and included a large number of acute stroke patients $(\mathrm{n}=2,901)$. We only included studies which used consecutive admissions of acute stroke patients. Both previous reviews in this area were narrative reviews with no meta-analysis $[9,10]$. We also included a significant number of acute stroke patients from additional publications that have not been considered in these reviews.

The main weakness of our review was the heterogeneity of the studies. This includes the varying troponin assays and cutoffs, the variable exclusion of patients with preexisting cardiac/renal disease and the different study settings. Although relatively few studies included a multivariate analysis, the pooled analysis of those studies was generally consistent with the pooled univariate analysis. We are also not able to explain the underlying pathophysiology of raised troponin in acute stroke.

The results of this review raise the question as to whether troponin should be routinely checked in patients with acute stroke. Recent UK acute stroke guidelines from the National Institute of Clinical Excellence [22] and the Scottish Intercollegiate Guidelines Network [23] do not recommend the routine checking of cardiac enzymes. However, the American Stroke Association [24] does recommend this. They state the frequent finding of coexisting cardiac disease, including acute coronary syndromes, as the justification. Further research is required to determine the clinical utility of routine troponin testing after acute stroke.

In summary, elevated troponin after acute stroke appears to be common, occurring in up to 1 in 5 patients, and is associated with an increased risk of death.

\section{References}

1 Barber M, Morton JJ, Macfarlane PW, Barlow N, Roditi G, Stott DJ: Elevated troponin levels are associated with sympathoadrenal activation in acute ischaemic stroke. Cerebrovasc Dis 2007;23:260-266.

-2 Jensen JK, Kristensen RS, Bak S, Atar D, Hoilund-Carlsen PF, Mickley H: Frequency and significance of troponin T elevation in acute ischemic stroke. Am J Cardiol 2007;99:108112.

-3 Ay H, Koroshetz WJ, Benner T, Vangel MG, Melinosky C, Arsava EM, Ayata C, Zhu M, Schwamm LH, Sorensen AG: Neuroanatomic correlates of stroke-related myocardial injury. Neurology 2006;66:1325-1329.

4 Christensen H, Johannesen $\mathrm{HH}$, Christensen AF, Bendtzen K, Boysen G: Serum cardiac Troponin I in acute stroke is related to serum cortisol and TNF- $\alpha$. Cerebrovasc Dis 2004; 18:184-199.
5 Hachinski VC, Smith KE, Silver MD, Gibson CJ, Ciriello J: Acute myocardial and plasma catecholamine changes in experimental stroke. Stroke 1986;17:387-390.

6 Atam V, Chandra AS, Chandra AN, Verma S, Saxena A, Singh K: Troponin T and acute stroke outcomes in the young. J Intern Med India 2005;8:58-60.

7 Di Angelantonio E, Fiorelli M, Toni D, Sacchetti ML, Lorenzano S, Falcou A, Ciarla MV, Suppa M, Bonanni L, Bertazzoni G, Aguglia F, Argentino C: Prognostic significance of admission levels of troponin I in patients with acute ischaemic stroke. J Neurol Neurosurg Psychiatry 2005;76:76-81.

$>8$ Fure B, Bruun Wyller T, Thommessen B: Electrocardiographic and troponin T changes in acute ischaemic stroke. J Intern Med 2006;259:592-597.

-9 Jespersen CM, Hansen JF: Myocardial stress in patients with acute cerebrovascular events. Cardiology 2008;110:123-128.
10 Jensen JK, Atar D, Mickley H: Mechanism of troponin elevations in patients with acute ischaemic stroke. Am J Cardiol 2007;99:867870 .

11 Stroop DF, Berlin JA, Morton SC, Olkin I, Williamson GD, Rennie D, Moher D, Becker BJ, Sipe T, Thacker SB: Meta-analysis of observational studies in epidemiology: a proposal for reporting. JAMA 2000;283:20082012.

12 Higgins JPT, Green S (eds): Cochrane Handbook for Systematic Reviews of Interventions, Version 5.0.1 (updated September 2008). Clayton, The Cochrane Collaboration, 2008.

13 Apak I, Iltumer K, Tamam Y, Nurettin K: Serum cardiac troponin $T$ levels as an indicator of myocardial injury and hemorrhagic stroke patients. Tohoku J Exp Med 2005;205:93101. 
-14 Iltumur K, Karabulut, Apuk I, Aluclu U, Ariturk Z, Toprak N: Elevated plasma N-terminal pro-brain natriuretic peptide levels in acute ischemic stroke. Am Heart J 2006;151: 1115-1122.

-15 Maliszewska M, Fiszer U, Palasik W, Tadeusiak W, Morton M: Prognostic role of troponin I in ischemic stroke. Polski Merkuriusz Lekarski 2005;19:158-161.

- 16 Etgen T, Baum H, Sander K, Sander D: Cardiac troponins and $\mathrm{N}$-terminal pro-brain natriuretic peptide in acute ischemic stroke do not relate to clinical prognosis. Stroke 2005;36:270-275.

-17 Guerrero-Peral AB, Guerrero-Peral AL, Carrascal Y, Bustamante R, Rodriguez MA, Ponce-Villares MA, Bueno-Rodriguez V: Specific markers of myocardial injury in acute stroke. Rev Neurol 2002;35:901-904.
8 Ay H, Arsava EM, Saribas O: Creatine kinase-MB elevation after stroke is not cardiac in origin. Stroke 2002;33:286-289.

19 Trooyen M, Indredavik B, Rossvoll O, Slordahl SA: Myocardial injury in acute stroke assesses by troponins. Tidsskr Nor Laegeforen 2001;121:421-425.

20 James P, Ellis CJ, Whitlock RML, McNeil AR, Henley J, Anderson NE: Relation between troponin $\mathrm{T}$ concentration and mortality in patients presenting with an acute stroke: observational study. BMJ 2000;320: 1502-1504.

21 Jaffe AS, Babuin L, Apple FS: Biomarkers in acute cardiac disease. J Am Coll Cardiol 2006;48:1-11.
22 National Institute of Clinical Excellence: Acute Stroke and TIA Clinical Guidelines (draft). London, NICE, 2008. http://www. nice.org.uk/guidance/index.jsp? action=byID\&o=11646 (accessed June 26, 2008).

23 Scottish Intercollegiate Guidelines Network: Management of Patients with Stroke: Assessment, Investigation, Immediate Management and Secondary Prevention (draft). Glasgow, SIGN, 2008.

24 American Heart Association/American Stroke Association Guideline: Guidelines for the Early Management of Adults with Ischaemic Stroke. Dallas, AHA, 2007. http:// stroke.ahajournals.org/cgi/reprint/ STROKEAHA.107.181486 (accessed June 26, 2008) 